(c) American Dairy Science Association, 2004.

\title{
Genotype $\times$ Environment Interaction for Grazing vs. Confinement. II. Health and Reproduction Traits*
}

\author{
J. F. Kearney, ${ }^{1}$ M. M. Schutz, ${ }^{1}$ and P. J. Boettcher ${ }^{2}$ \\ ${ }^{1}$ Department of Animal Sciences, \\ Purdue University, West Lafayette, IN 47907 \\ ${ }^{2} \mathrm{ANAFI}$, Cremona, Italy
}

\section{ABSTRACT}

Continual selection for increased milk yield for more than $40 \mathrm{yr}$, combined with the antagonistic relationship between increasing yield, somatic cell count, and fertility, have resulted in sires that may not be optimal for producing daughters for grazing systems where seasonal calving is very important. The objective of this study was to investigate the possible existence of a genotype $\times$ environment interaction $(\mathrm{G} \times \mathrm{E})$ in grazing vs. confinement herds within the United States for lactation average somatic cell score (LSCS), days open (DO), days to first service (DFS), and number of services per conception (SPC). Grazing herds were defined as those that utilized grazing for at least 6 mo each year and were enrolled in Dairy Herd Improvement (DHI). Control herds were confinement DHI herds of similar size in the same states. For LSCS, the performance of daughters in grazing and control herds was examined using linear regression of LSCS on the November 2000 USDA-DHIA sire predicted transmitting abilities (PTA) for SCS. Genetic parameters for all traits were estimated using REML in a bivariate animal model that treated the same trait in different environments as different traits. Rank correlations were calculated between sires' estimated breeding values for LSCS, calculated separately for sires in both environments. The coefficient of regression of daughter LSCS on sire PTA was less in grazing herds than in control herds. The coefficient of regression for control herds was closer to expectation. Estimates of heritability were approximately 0.12 for LSCS, and less than 0.05 for the reproduction traits. Heritabilities for DO, DFS, and SPC were slightly higher for control herds. Estimates of genetic correlation for each reproductive trait between the 2 environments were high and not significantly dif-

Received October 11, 2001.

Accepted August 22, 2003.

Corresponding author: M. M. Schutz, e-mail: mschutz@purdue. edu.

*Contribution No. 16648 of Purdue University Agricultural Research Program.

ferent from unity. Generally, these traits appear to be under similar genetic control, but a lower coefficient of regression of LSCS on sire PTA for SCS in grazing herds suggests differences in daughter performance in grazing herds may be overstated based on current PTA for SCS.

(Key words: genotype $\times$ environment interaction, grazing, health, reproduction)

Abbreviation key: DO = days open, DFS = days to first service, $\mathbf{G} \times \mathbf{E}=$ genotype $\times$ environment interaction, LSCS = lactation average somatic cell score, SPC $=$ services per conception.

\section{INTRODUCTION}

Selection for increased milk production has undoubtedly meant greater efficiency of production for dairy producers over the years. However, dairy producers are increasingly recognizing the value of improving other traits such as SCC, fertility, and longevity to increase the efficiency of their operations. The national selection indices have been modified to reflect this shifting emphasis to nonproduction traits, and genetic evaluations for lactation average SCC (LSCS) and daughter pregnancy rate based on the number of days a cow remains open (DO) are now reported on a quarterly basis to the US dairy industry.

High SCC result in loss of profit via losses in quality premiums, decreased production from subclinical mastitis, and increased costs for the treatment of clinical mastitis. Annual losses from mastitis have been estimated at approximately $\$ 180$ per cow (Jasper et al., 1982; Dunklee et al., 1994). Reproductive failure has been reported to account for $20 \%$ of cows culled in the northeastern United States (Bascom and Young, 1998) and up to $28 \%$ in Sweden (Philipsson, 1981). Failure to conceive may be a greater problem for producers who practice intensive grazing, as seasonal calving is an integral part of their management system.

Genotype $\times$ environment interaction $(\mathbf{G} \times \mathbf{E})$ is a concern for grazing herds because current AI sire evaluations are based predominantly on daughters producing in high-input systems. If $\mathrm{G} \times \mathrm{E}$ exists, then grazing 
herds may not maximize genetic gain by selecting among the top sires based on current sire evaluations. Generally, there has been little evidence for the presence of $\mathrm{G} \times \mathrm{E}$ for production traits (Cromie et al., 1998; Weigel et al., 1999; Boettcher et al., 2003). Few studies have reported on $\mathrm{G} \times \mathrm{E}$ for SCS or mastitis. Banos and Shook (1990) estimated large product-moment correlations for sire effects in different levels of herd-year average SCS. Castillo-Juarez et al. (2000) estimated a genetic correlation of 0.981 for SCS between high and low environments based on different levels of herd mature equivalent milk. In Scotland, Pryce et al. (1999) found no interaction for mastitis for cows fed either a high or low concentrate diet. For Canadian Holsteins, Boettcher et al. (2003) found a genetic correlation of unity between cows in grazing and control environments for the conformation trait, mammary system.

Reproduction involves the complex interaction of genetics, nutrition, and physiology. Estimates of heritabilities and genetic variance for reproductive traits are low, less than 10\% (Philipsson, 1981; Seykora and McDaniel, 1983; Faust et al., 1989), indicating that response to selection for these traits as defined in those studies would be slow. Also, milk yield and fertility traits appear to be antagonistic (Hansen et al., 1983; Van Arendonk, 1989; Marti and Funk, 1994; Rauw et al. 1998). In long-term selection studies, cows that were selected for increased milk (Hageman et al., 1991) and fat plus protein (Pryce et al., 1999) had reduced fertility vs. cows in the control lines.

Indeed, dairy producers in several grazing countries, notably Ireland and New Zealand, have expressed concern regarding the declining fertility of cows with increased Holstein genes. In Ireland, Dillion and Buckley (1998) reported that high genetic merit cows had an overall infertililty rate of $25 \% \mathrm{vs.} 6 \%$ for medium genetic merit cows. Harris and Winkelman (2000) and Verkerk et al. (2000) reported significant differences between cows of New Zealand origin and North American origin for conception rate, services per conception (SPC), and days to first service (DFS). Early negative energy balance from the failure of cows to match intake with high production has been implicated as a reason for reduced fertility (Harrison et al., 1989; Staples et al., 1990; Nebel and McGilliard, 1993; Butler, 2000; Veerkamp et al., 2000). This has important implications for grazing herds, as the energy intake of cows postcalving is often less than in confinement. This may result in weight loss and prolonged negative energy balance, ultimately reducing fertility.

Results directly exploring the existence of $\mathrm{G} \times \mathrm{E}$ for reproduction traits are scant. However, Boettcher et al. (2003) reported only a modest correlation of 0.64 between calving interval in grazing herds and calving interval in conventional herds. In their study, heritability in grazing herds (0.052), though small, was nearly twice that in conventional herds (0.027).

The objective of this study was to investigate the possibility of a $\mathrm{G} \times \mathrm{E}$ for LSCS and selected reproduction traits for Holsteins producing in grazing or confinement systems in the eastern United States.

\section{MATERIALS AND METHODS}

Grazing herds were defined as those in which cows consumed the majority of their forage from grass for at least $6 \mathrm{mo}$ of the year. These herds were identified with the help of DHIA personnel, dairy specialists, and grazing consultants who were asked to identify herds and to ascertain that they were utilizing grazing as defined here. Herds had to be enrolled in a DHI recording program. Data were provided by Dairy Record Management Services (DRMS, Raleigh, NC) and AgSource, Inc. (Verona, WI). In addition, herds of similar size from the same states but not known to be utilizing grazing were selected as control herds, and it may be possible that there were a small number of grazing herds among these. The DO, DFS, and the number of SPC were used as indicators of reproductive performance. Not all herds reported reproductive data to the record-processing centers, although DO was verified when possible based on subsequent calving dates. Records for LSCS, DFS, and SPC were available for DRMS herds only, whereas DO were available from both processing centers. A summary of the number of records, cows, and herds for each trait is provided in Table 1. Further information about the general characteristics and differences in milk, fat, and protein yield among these herds are presented in a companion paper (Kearney et al., 2003).

Edits applied to the dataset were as follows: 1) only records after 1990 were included, 2) cows were required to have a first lactation, 3) cows were required to have pedigree information, 4) parities greater than 5 were deleted, 5) cows with $<60$ DIM for each group were deleted, 6 ) cows with $<20$ and $>400$ DO were excluded, and 7) records initiated by abortions were deleted. Pedigree information was provided by the USDA's Animal Improvement Programs Laboratory.

The performance of daughters in grazing and confinement for LSCS was examined using linear regression of daughter LSCS on the November 2000 USDADHIA PTA of their sires for SCS with the following model:

$$
\mathrm{Y}_{i j k l}=\mathrm{h}_{i}+\mathrm{ys}_{j}+\mathrm{a}_{k}+\beta \mathrm{PTA}_{i j k l}+\mathrm{e}_{i j k l},
$$

where $\mathrm{Y}_{i j k l}=$ first-lactation LSCS for cow $\mathrm{l}$ in herd $i$, calving in year-season $j$, in age-parity class $k ; \mathrm{h}_{i}=$ fixed 
Table 1. Number of herds, records, and cows for somatic cell scores (SCS), days open (DO), days to first service (DFS), and services per conception (SPC).

\begin{tabular}{|c|c|c|c|c|c|c|}
\hline \multirow[b]{2}{*}{ Variable } & \multicolumn{2}{|c|}{ SCS } & \multicolumn{2}{|c|}{ DO } & \multicolumn{2}{|c|}{ DFS/SPC } \\
\hline & Grazing & Control & Grazing & Control & Grazing & Control \\
\hline Herds, No. & 348 & 368 & 297 & 398 & 147 & 322 \\
\hline Records, No. & 79,905 & 128,256 & 39,727 & 80,934 & 5367 & 16,376 \\
\hline Cows, No. & 32,200 & 53,368 & 19,860 & 39,654 & 4433 & 16,341 \\
\hline
\end{tabular}

effect of herd $i ; \mathrm{ys}_{j}=$ fixed effect of the year-season of calving $j ; \mathrm{a}_{k}=$ fixed effect of age class $k ; \beta=$ coefficient of regression of daughter LSCS on sire PTA; $\mathrm{PTA}_{i j k l}=$ November 2000 USDA-DHIA PTA for LSCS of the sire of cow 1 ; and $\mathrm{e}_{i j k l}=$ random residual.

The univariate regression model was fitted separately to grazing and control data. Regression coefficients were estimated using the PROC GLM of SAS (SAS Inst., Inc., Cary, NC) for all first-lactation records and for 4 random subsets for LSCS. A requirement of regression analysis was that cows have an AI sire with USDA-DHIA PTA for LSCS. Seasons 1 to 4 were defined as January to March, April to June, July to September, and October to December. Within each herd, seasons with a single record were merged with the nearest season with at least 1 record. Herd and year season effects were considered separately in the model for computational feasibility.

The (co)variance component estimation program, VCE4 (Neumaier and Groeneveld, 1998), was used to estimate heritabilities and genetic correlations between the 2 environments for each trait. The REML method chosen for this study was analytical gradients (Neumaier and Groeneveld, 1998). A bivariate animal model that considered traits in different environments as separate traits was used to estimate the variance components.

Due to the large computational demands, heritabilities and genetic correlations were estimated for 4 random subsets for LSCS and 2 subsets for DO. These traits were analyzed separately and considered as lactation measures unadjusted for milk production. The numbers of records for the other 2 traits were such that the complete dataset could be analyzed at once. Milk on the second test day after calving was used as a covariate in the analysis of DFC and SPC, since DFC may be largely dictated by a voluntary waiting period that may be intentionally related to milk yield observed, and SPC may be influenced by energy balance that may be more severe in higher producing cows. Milk was not considered as a covariate in the model for DO since test-day records were not obtained for records from WI. To assess the level of reranking among sires within each environment for LSCS, rank correlations between sires' EBV were calculated using PROC CORR (SAS Inst., Inc.). Correlations were calculated for sires that had at least 5 daughters producing in both grazing and confinement herds. Predicted breeding values were obtained for all sires separately in both the grazing and confinement groups using PEST (Groeneveld and Kovac, 1990). Rank correlations were also calculated between the sires' EBV in either grazing or control systems with their November 2000 USDA-DHIA PTA for SCS.

The following model was used for the estimation of the genetic parameters and breeding values:

$$
\mathrm{Y}_{i j k l}=\operatorname{hys}_{i}+\mathrm{ap}_{j}+\left(\beta \mathrm{tdm} 2_{l}\right)+\mathrm{a}_{k}+\mathrm{pe}_{k}+\mathrm{e}_{i j k l},
$$

where $\mathrm{Y}_{i j k l}=\mathrm{LSCS}, \mathrm{DO}, \mathrm{DFC}$, or SPC for animal $k$ calving in herd-year-season $i$, in age-parity class $j$; hys h $_{i}$ $=$ fixed effect of herd-year-season of calving $i ; \mathrm{ap}_{j}=$ fixed effect of age-parity class $j$; $\beta$ tdm $2_{l}=$ regression of trait on second test-day milk yield (for DFS and SPC); $\mathrm{a}_{k}=$ random additve genetic effect of animal $k ; \mathrm{pe}_{k}=$ random effect of permanent environment for cow $k$; and $\mathrm{e}_{i j k l}=$ random residual.

Overall estimates presented in this paper are the mean of estimates for each of the subsets, weighted by the number of observations in each subset. Overall standard errors were estimated as the empirical standard errors of the subset estimates of heritabilities and genetic correlations.

\section{RESULTS AND DISCUSSION}

Means and standard deviations for each of the traits are provided in Table 2. The LSCS was numerically higher for the grazing herds than for the controls herds.

Table 2. Summary of somatic cell score and reproduction data for grazing and control herds.

\begin{tabular}{lccccc}
\hline & \multicolumn{2}{c}{ Grazing } & & \multicolumn{2}{c}{ Control } \\
\cline { 2 - 3 } \cline { 6 - 7 } Trait & Mean & SD & & Mean & SD \\
\hline LSCS & 3.19 & 1.50 & & 2.92 & 1.52 \\
Days open d & 154 & 88 & & 148 & 83 \\
Days to first service, d & 106 & 69 & & 104 & 57 \\
Services per conception, No. & 2.87 & 2.05 & & 2.50 & 1.76 \\
\hline
\end{tabular}


Table 3. Coefficients of regression (standard errors) of lactation average somatic cell score on November 2000 USDA-DHIA sire predicted transmitting abilities for grazing and control herds for all records and 4 random subsets.

\begin{tabular}{|c|c|c|}
\hline \multirow{2}{*}{$\begin{array}{l}\text { Item } \\
\text { All records }\end{array}$} & Grazing & Control \\
\hline & $0.88(0.085)$ & $0.96(0.063)$ \\
\hline \multicolumn{3}{|c|}{ Random Subset } \\
\hline A & $0.81 *(0.085)$ & $0.88(0.064)$ \\
\hline B & $0.88(0.080)$ & $0.85(0.060)$ \\
\hline $\mathrm{C}$ & $0.92(0.080)$ & $1.14 * *(0.062)$ \\
\hline D & $0.91 \quad(0.072)$ & $0.97(0.063)$ \\
\hline
\end{tabular}

*Significantly different from $1(P<0.05)$.

**Significantly different from $1(P<0.01)$.

Cows on pasture might be expected to have a lower SCS; however, there was a disproportionate number of grazing cows to control cows for Southern states, especially Louisiana and Mississippi (Kearney et al., 2003), where SCS may be higher due to the hot and humid climate (Schutz et al., 1994). Likewise, the reproductive performance of the grazing cows is slightly lower than that of the control cows, but similar to expected benchmarks (Indiana State Dairy Association, 2000). It is possible this could be attributed to the unsuitability of the genetics of these cows for pasturebased systems, but more likely can be attributed to a greater majority of grazing cows in Southern states, as well. Nevertheless, 154 DO on average would make seasonal calving very difficult. However, there was significant variation around these means, as evidenced by the relatively large standard deviations.

Coefficients of regression of daughter first lactation LSCS on USDA-DHIA sire PTA for SCS for the overall and random subsets are in Table 3. The expectation of the coefficients was 1 , although reliabilities were likely lower than one would observe for yield traits, such as milk, fat, and protein, with higher heritability. The coefficients of regression reported here are lower than the coefficient of regression of first lactation average
SCS on PTA SCS of 1.3 reported by Cranford and Pearson (2001). For the grazing group, only one subset produced a regression coefficient that was significantly less than expectation. One random subset in the control group was significantly greater than 1 . The coefficients suggest that daughter differences expected from selecting current sires based on PTA for SCS will be slightly lower in the grazing herds than in control herds. Nevertheless, selection based on current PTA for SCS should be successful under both environments.

Estimates of heritabilities, genetic correlations, and variance ratios for the permanent environmental effect for SCS are given in Table 4. Heritabilities ranged from 0.1 to 0.15 and are in agreement with previous estimates (Banos and Shook, 1990; Schutz 1994). Differences between heritabilities for the 2 systems were small and negligible, and pooled estimates of total phenotypic variance were $1.85 \mathrm{LSCS}^{2}$ and $1.96 \mathrm{LSCS}^{2}$ for grazing and control herds, respectively. Since LSCS in grazing and control herds were treated as separate traits, the estimates of genetic correlation indicate the extent to which the 2 traits are influenced by the same genes, and also the amount of reranking expected among sires between the 2 environments. For the overall data set, the genetic correlation for LSCS of 0.89 was not significantly different from unity, indicating the LSCS is under the control of the same genes in the 2 environments. Two of the random subsets differed from unity, but this could probably be attributed to sampling error. Permanent environmental effects accounted for about $20 \%$ of the variation associated with LSCS in both environments. Rank correlations between grazing and control groups were estimated for 778 sires common to both (Table 5). The rank correlation between EBV from grazing and control groups was 0.49 . The rank correlations between the control EBV and the USDA-DHIA PTA were higher (0.7) than the correlation between the grazing EBV and the USDA-DHIA PTA (0.59). The mean rank change between grazing

Table 4. Estimates of $\mathrm{h}^{2}$, permanent environmental variance relative to phenotypic variance $\left(\mathrm{c}^{2}\right)$, and genetic correlations for 4 subsets, and weighted average estimates for LSCS in grazing and control systems. Standard errors are in parentheses.

\begin{tabular}{lllllll}
\hline & \multicolumn{2}{c}{ Grazing } & & \multicolumn{2}{c}{ Control } & \\
\cline { 2 - 3 } Item & $\mathrm{h}^{2}$ & $\mathrm{c}^{2}$ & & $\mathrm{~h}^{2}$ & $\mathrm{c}^{2}$ & \\
\hline Subset & & & & & & \\
$\mathrm{A}$ & $0.13(0.014)$ & $0.23(0.014)$ & & $0.14(0.010)$ & $0.21(0.010)$ & $0.79(0.070)$ \\
$\mathrm{B}$ & $0.12(0.017)$ & $0.23(0.017)$ & & $0.13(0.012)$ & $0.22(0.011)$ & $0.97(0.097)$ \\
$\mathrm{C}$ & $0.15(0.013)$ & $0.19(0.012)$ & & $0.15(0.01)$ & $0.20(0.010)$ & $0.83(0.063)$ \\
$\mathrm{D}$ & $0.1(0.012)$ & $0.24(0.012)$ & & $0.12(0.009)$ & $0.218(0.009)$ & $0.98(0.029)$ \\
Overall $^{1}$ & $0.12(0.010)$ & $0.22(0.011)$ & & $0.13(0.006)$ & $0.21(0.005)$ & $0.89(0.062)$ \\
\hline
\end{tabular}

${ }^{1}$ Overall standard errors were estimated as the empirical standard errors of the subset estimates of $h^{2}$ and genetic correlations. 
Table 5. Rank correlations for somatic cell scores (SCS) for sires in grazing and confinement and with USDA-DHIA PTA for lactation average SCS (November, 2000) (USDA).

\begin{tabular}{lll}
\hline Item & Grazing EBV & USDA-DHIA PTA \\
\hline Control EBV & 0.49 & 0.70 \\
Grazing EBV & & 0.59 \\
\hline
\end{tabular}

and control herds was 29 for the top 100 sires based on sires' EBV in control herds. This indicates that reranking can occur when evaluations are calculated within environment, although estimated correlations may be less than 1 given the low reliability of the EBV.

Estimates of heritabilities, genetic correlations, and permanent environmental effects for DO, DFS, and SPC are given in Table 6. Heritabilities for all traits were low, ranging from 0.5 to $5 \%$, and are in agreement with several studies (Seykora and McDaniel, 1983; Van Arendonk et al., 1989; Marti and Funk, 1994). Heritabilities were slightly higher for the control herds for all traits, but differences were small. Such low estimates indicate that environmental and nonadditive genetic factors contribute most to the variation associated with the traits. Estimates of phenotypic variance were $6935^{2} \mathrm{~d}, 3465 \mathrm{~d}^{2}$, and 3.43 services $^{2}$, respectively, for the 3 traits in grazing, and $6163 \mathrm{~d}^{2}, 2519 \mathrm{~d}^{2}$, and 2.65 services $^{2}$, respectively, for control environments. More total variation existed for the grazing herds in this study, but whether that arose from sampling error or is truly the case would require additional herds and cows with observations for these traits.

For DO, the estimated genetic correlation was different from unity for 1 subset, but not for the other. The overall estimate, an average of the 2 subsets weighted by the number of observations, was not different from unity either. Sampling error could account for the lower estimate. Estimates of genetic correlations were at unity for both DFS and SPC, indicating that the traits are under identical genetic control in both environments, although the possibility that spurious results arose from sampling error and small numbers of records cannot be precluded in this initial study. Estimates of permanent environment were around $6 \%$ for DO but fluctuated widely for DFS and SPC. This also can be attributed to the relatively small number of records, and especially repeated records, for these traits. For DFS and SPC, very limited data existed, especially in the grazing herds, where breeding information may not be as readily observed.

Information on live weight, BCS, and weight loss postcalving were not available for this study. Aforementioned studies have indicated that as milk production has increased, the reproductive capacity of these animals has declined. Failure to match nutritional demands has been suggested as the main reason for the decline in reproductive performance. High-producing cows are not consuming enough energy to cope with the demands of production and reproduction simultaneously. This in itself raises many questions for grazing herds regarding the suitability of high-producing cows because the energy intake of grazing cows is less than intake in confinement.

For grazing herds, the data came from many herds in Louisiana (Kearney et al., 2003). The rather extreme heat and humidity in the southern United States would be more stressful to cows and may have resulted in more variation in reproductive measures. This makes it uncertain whether comparisons of results from studies in very moderate climates, such as New Zealand and Ireland, are strictly valid. Nevertheless, it is worthwhile to consider those sources since work from North America is scarce. In New Zealand, Kolver et al. (2000) reported that heifers of overseas origin (primarily North American) were unable to maintain acceptable body condition and live weight on an all-pasture diet compared with New Zealand heifers, questioning the suitability of the overseas Holstein-Friesian genotype for seasonal pasture production systems. In Ireland, Snijders et al. (2001) similarly reported that cows of high genetic merit had a lower BCS at calving and lost

Table 6. Estimates of $\mathrm{h}^{2}$, permanent environment variance relative to phenotypic variance $\left(\mathrm{c}^{2}\right)$, and genetic correlations for days open (DO), days to first service (DFS), and number of services per conception (SPC). Standard errors are in parentheses.

\begin{tabular}{|c|c|c|c|c|c|}
\hline \multirow[b]{2}{*}{ Item } & \multicolumn{2}{|c|}{ Grazing } & \multicolumn{2}{|c|}{ Control } & \multirow[b]{2}{*}{$r_{\text {grazing,control }}$} \\
\hline & $\mathrm{h}^{2}$ & $c^{2}$ & $\mathrm{~h}^{2}$ & $c^{2}$ & \\
\hline \multicolumn{6}{|l|}{ DO } \\
\hline Subset A & $0.024(0.006)$ & $0.060(0.010)$ & $0.032(0.005)$ & $0.045(0.007)$ & $1.000(0.000)$ \\
\hline Subset B & $0.032(0.002)$ & $0.038(0.007)$ & $0.036(0.005)$ & $0.047(0.011)$ & $0.743(0.120)$ \\
\hline DFS & & & & & \\
\hline $\begin{array}{l}\text { All records } \\
\text { SPC }\end{array}$ & $0.020(0.010)$ & $0.640(0.025)$ & $0.047(0.009)$ & $0.0(0.000)$ & $1.000(0.000)$ \\
\hline All records & $0.007(0.006)$ & $0.775(0.018)$ & $0.030(0.007)$ & $0.460(0.120)$ & $1.000(0.000)$ \\
\hline
\end{tabular}


more body condition from calving to first service than medium genetic cows, despite the high-merit group having a significantly higher total DMI. If a similar pattern for body condition and weight loss existed for grazing herds in the United States, the ability to rebreed cows rapidly and achieve seasonal calving would be restricted. The mean DO and the DFS reported here are long and tend to suggest that seasonal calving would be difficult, but the reasons for this are unclear from the information available.

\section{CONCLUSIONS}

The ability of grazing herds to select among the top sires is reduced if significant $\mathrm{G} \times \mathrm{E}$ is present between grazing and confinement systems. After many years of selecting solely on milk production traits, there is now a shift toward milk quality, health, and fertility. Premiums for good-quality milk, financial losses associated with mastitis, and high cow replacement costs mean it is important to consider these health and fertility traits in breeding programs. Despite the low estimates of heritability for the traits analyzed, there is still genetic variation for the traits. Also, traits with moderate heritabilities, such BCS (Dechow et al., 2001; Pryce et al., 2001), energy balance, and live weight (Veerkamp et al., 2000) may be useful in both management and breeding programs to improve reproductive performance.

Results of this initial study do not provide evidence for the existence of a $\mathrm{G} \times \mathrm{E}$ for LSCS, DO, DFS, or SPC for the environments defined. Limited reranking of sires' EBV for LSCS, when evaluations are done within environment, does raise the possibility of imperfections of current evaluations for accurate prediction in grazing situations. However, it is likely that selecting among the top sires based on current evaluations will make nearly optimal genetic progress. Future work with larger numbers of records is necessary before definitive conclusions may be drawn about traits with such low heritability.

\section{ACKNOWLEDGMENTS}

This study was funded in part by the USDA's Sustainable Agriculture Research and Education (SARE) program in Lincoln, NE, and the National Association of Animal Breeders in Columbia, MO. The authors wish to thank the numerous individuals who contributed data to the study, especially J. Clay and C. Vierhout of DRMS, Raleigh, NC, and $\mathrm{K}$. Weigel of University of Wisconsin for supplying the records.

\section{REFERENCES}

Banos, G., and G. E. Shook. 1990. Genotype by environment interaction and genetic correlations among parities for somatic cell count and milk yield. J. Dairy Sci. 73:2563-2573.
Bascom, S. S., and A. J. Young. 1998. A summary of the reasons why farmers cull cows. J. Dairy Sci. 81:2299-2305.

Butler, W. R. 2000. Nutritional interactions with reproductive performance in dairy cattle. Anim. Reprod. Sci. 60-61:449-457.

Castillo-Juarez, H., P. A. Oltenacu, R. W. Blake, C. E. McCulloch, and E. G. Cienfuegos-Rivas. 2000. Effect of herd environment on the genetic and phenotypic relationships among milk yield, conception rate, and somatic cell score in Holstein cattle. J. Dairy Sci. 83:807-814.

Cranford, J. L., and R. E. Pearson. 2001. Relationships of sire predicted transmitting ability for somatic cell score with measures of daughter performance. J. Dairy Sci. 84:1501-1507.

Cromie, A. R., D. L. Kelleher, F. J. Gordon, and M. Rath. 1998. Genotype by environment interaction for milk production traits in Holstein Friesian dairy cattle in Ireland. Pages 100-104 in Proc. INTERBULL Open Mtg., Rotorua, New Zealand. Bulletin No. 18, INTERBULL, Uppsala, Sweden.

Dechow, C. D., G. W. Rogers, and J. S. Clay. 2001. Heritabilities and correlations among body condition scores, production traits, and reproductive performance. J. Dairy Sci. 84:266-275.

Dillion, P., and F. Buckley. 1998. Managing and feeding high genetic merit dairy cows at pasture. $R \& H$ Hall Technical Bulletin, Issue No. 2. RPH Hall, Dublin, Ireland.

Dunklee, J. S., A. E. Freeman, and D. H. Kelley. 1994. Comparison of Holsteins selected for high and average milk production. 2. Health and reproductive response to selection for milk. J. Dairy Sci. 77:3683-3690.

Faust, M. A., B. T. McDaniel, and O. W. R. Robison. 1989. Genetics of reproduction in primiparous Holsteins. J. Dairy Sci. 72:194-201.

Groeneveld, E., and M. Kovac. 1990. A generalized computing procedure for setting up and solving mixed linear models. J. Dairy Sci. 73:513-531.

Hageman, W. H., G. E. Shook, and W. J. Tyler. 1991. Reproductive performance in genetic lines selected for high or average milk yield. J. Dairy Sci. 74:4366-4376.

Hansen, L. B., A. E. Freeman, and P. J. Berger. 1983. Yield and fertility relationships in dairy cattle. J. Dairy Sci. 66:293-305.

Harris, B. L., and A. M. Winkelman. 2000. Influence of North American Holstein genetics on dairy cattle performance in New Zealand. Proc. N.Z. Large Herds Conf. 6:122-136.

Harrison, R. O., S. P. Ford, J. W. Young, A. J. Conley, and A. E. Freeman. 1989. Increased milk production versus reproductive and energy status of high producing dairy cows. J. Dairy Sci. 73:2749-2758.

Indiana State Dairy Association. 2000. Page 23 in 110th Annual Report. Indiana State Dairy Assoc., West Lafayette, IN.

Kearney, J. F., M. M. Schutz, P. J. Boettcher, and K. A. Weigel. 2004. Genotype $\times$ environment interaction for grazing versus confinement. II. Production traits. J. Dairy Sci. 87:501-509.

Kolver, E. S., A. R. Napper, P. J. A. Copeman, and L. D. Muller. 2000. A comparison of New Zealand and overseas Holstein Friesian heifers. Proc. N.Z. Soc. Anim. Prod. 60:265-269.

Laben, R. L., R. D. Shanks, P. J. Berger, and A. E. Freeman. 1982. Factors affecting milk yield and reproductive performance. 65:1004-1015.

Jasper, D. E., J. S. McDonald, R. D. Mocherie, W. N. Philpot, R. J. Farnsworth and S. B. Spencer. 1982. Bovine mastitis research: Needs, funding, and sources of support. Page 184 in Proc. 21st Annu. Mtg. Natl. Mastitis Council. Natl. Mastitis Council, Arlington, VA.

Marti, C. F., and D. A. Funk. 1994 Relationship between production and days open at different levels of herd production. J. Dairy Sci. 77:1682-1690.

Nebel, R. L., and M. L. McGilliard. 1993. Interactions of milk yield and reproductive performance in dairy cows. J. Dairy Sci. 76:3257-3268.

Neumaier, A., and E. Groeneveld. 1998. Restricted maximum likelihood estimation of covariances in sparse linear models. Genet. Sel. Evol. 30:3-26.

Pryce, J. E., B. L. Nielsen, R. F. Veerkamp, and G. Simm. 1999. Genotype and feeding system effects and interactions for health and fertility traits in dairy cattle. Livest. Prod. Sci. 57:193-201. 
Pryce, J. E., M. P. Coffey, and G. Simm. 2001. The relationship between body condition score and reproductive performance. J. Dairy Sci. 84:1508-1515.

Philipsson, J. 1981. Genetic aspects of female fertility in dairy cattle. Livest. Prod. Sci. 8:307-319.

Rauw, W. M., E. Kanis, E. N. Noordhuizen-Stassen, and F. J. Grommers. 1998. Undesirable side effects of selection for high production efficiency in farm animals: A review. Livest. Prod. Sci. 56:15-33.

Schutz, M. M., P. M. VanRaden, and G. R. Wiggans. 1994. Genetic variation in lactation means of somatic cell scores for six breeds of dairy cattle. J. Dairy Sci. 77:284-293.

Schutz, M. M. 1994. Genetic evaluation of somatic cell scores for United States dairy cattle. J. Dairy Sci. 77:2113-2129.

Seykora, A. J., and B. T. McDaniel. 1983. Heritabilities and correlations of lactation yields and fertility for Holsteins. J. Dairy Sci. 66:1486-1493.

Snijders, S. E. M., P. G. Dillion, K. J. O'Farrel, M. Disken, A. R. G. Wylie, D. O'Callaghan, M. Rath, and M. P. Boland. Genetic merit for milk production and reproductive success in dairy cows. Anim. Reprod. Sci. 65:17-31.

Staples, C. R., W. W. Thatcher, and J. H. Clark. 1990. Relationship between ovarian activity and energy status during the early postpartum period of high producing dairy cows. J. Dairy Sci. 73:938-947.

Van Arendonk, J. A. M., R. Hovenier, and W. De Boer. 1989. Phenotypic and genetic association between fertility and production in dairy cattle. Livest. Prod. Sci. 21:1-12.

Veerkamp, R. F., J. K. Oldenbroek, H. J. Van Der Gaast, and J. H. J. Van Der Werf. 2000. Genetic correlation between days until start of luteal activity and milk yield, energy balance, and live weights. J. Dairy Sci. 83:577-583.

Verkerk, G. A., S. Morgan, and E. S. Kolver. 2000. Comparison of selected reproductive characteristics in Overseas and New Zealand Holstein-Friesian cows grazing pasture or fed a total mixed ration. Proc. N.Z. Soc. Anim. Prod. 60:270-274.

Weigel, K. A., T. Kriegl, and A. L. Pohlman. 1999. Genetic analysis of dairy cattle production traits in a management intensive rotational grazing environment. J. Dairy Sci. 82:191-195. 